\title{
Russian aircraft industry: between forging ahead and falling behind
}

\author{
Irina Boyko \\ Logistics and Quality Management Department, \\ Saint-Petersburg State University for Services and Economics, \\ Belysheva, 4, App. 531, Saint Petersburg 193318, Russia \\ Fax: +7 (812) 6105722 \\ E-mail: boiko@finec.ru
}

\begin{abstract}
The evolution of the Russian development model adopted by the aviation industry is described in the article, with emphasis on the advanced level of basic research and poor performance of civil aircraft manufacturing. Critical analyses of the Russian 'administrative guidance' for the industry, based predominantly on substantial government financial subsistence, is introduced in the article as a policy shortage, requiring more sophisticated strategy to be elaborated and implemented by the federal government. Without explicit industrial policy, the country's aircraft industry has been shifting from forging ahead to falling behind. Abandoning the military-oriented strategy for the development of the aircraft industry, previously pursued by the USSR, has no explicit strategic goals for the development of its civil aviation industry.
\end{abstract}

Keywords: Russian aviation industry; catching up; forging ahead; falling behind; research and development; innovation system; institutional infrastructure; Russia.

Reference to this paper should be made as follows: Boyko, I. (2013) 'Russian aircraft industry: between forging ahead and falling behind', Int. J. Technology and Globalisation, Vol. 7, Nos. 1/2, pp.60-79.

Biographical notes: Irina Boyko is Full Doctor, Professor, and Head of the Logistics and Quality Management Department, Saint-Petersburg State University for Services and Economics. She is the General Director in Center for Regional and Innovation Policy. She is a Visiting Professor in Laurea University of Applied Science, Finland. She is a Visiting Researcher in Central European University, Hungary (2007), in University Quebec-a-Montreal (2006) and in Korea Institute for International Economic Policy, Korea (2005). She is a Fulbright scholar in University of Chicago, USA (2004-2005). She is an International Visiting Professor in Portland State University, USA (2001-2003). She holds a degree in Economics-Cybernetics from MA-Moscow State University in 1982. She received her PhD in Political Economy from Leningrad State University in 1991.

\section{Introduction}

The Russian aviation industry has been going through a very complicated stage in its life cycle. Inheriting from the USSR extensive R\&D experience and traditions, technological capabilities and substantial intellectual resources, today Russia is lagging behind on the 
international aerospace market. Today, ten years after the declaration of the Russian suzerainty and independence in late 1991, Russian aviation represents a steadily declining area of public and private activity.

Only at the beginning of the 21 st century, the Russian government has recognised the significant role which aviation should play in the further development of the Russian economy. Since then, the Russian government has tried various measures to restore the national aircraft industry. However, it becomes clear that political will, financial support and government procurements are not the only decisive recovery factors for the national aviation industry.

Our research highlights various aspects of the model of economic development pursued by the Russian aviation industry based on official publications.

Statistical data for our study was scarce. During the Soviet regime, about $80 \%$ of aerospace production was contracted for military purposes, implying high secrecy of the information. Following the subsequent market reforms, the lack of state guidance for industrial production in general and for the aviation industry in particular explains the inadequacy of the statistical information required for comprehensive analysis and examination.

\section{Theoretical background}

The quality of national economic growth based on intrinsic technological capabilities is quite different for the various groups of countries. As one outstanding economist writes, "classification of economic growth by various groups of countries: catching up, falling behind and leading countries (forging ahead) became very popular beginning in the 1960s (Soete and Verspagen, 1993).

In fact, the given classification of countries is based on the particularity of the technological policies they are pursuing. Hence, a definition of the national technological policy should be given. As we pointed out in our earlier publications, "presumably, technological policy per se is composed of creation, selection, adoption and diffusion of technologies pursued by national or regional governments. In fact, technological policy should be aimed at overcoming various social and economic challenges, faced at a certain time by a society. Thus, there is a direct link between technological policy and societal challenges to which it has to respond appropriately.

"Creation of technologies requires maintaining a national capability to conduct cutting-edge R\&D (basic, applied and developmental) and to possess an appropriate pool of knowledge and skills. Adoption of technologies requires specific skills to produce new goods and to trade them successfully on domestic or overseas markets. Speeding up diffusion (or spread) of commercially successful technologies among as many national companies as possible provides companies or regions with a higher accumulated commercial benefit and thus allows them to attain more sustainable economic growth. However, we would like to underline selection of new technologies as a very crucial process in linking national $R \& D$ (science) with commercial needs (private companies), making it possible to frame a specific spectrum where new technologies are oriented directly to obtaining good commercial results. In this regard, national companies operating within a particular market domain, seeking new technologies and having the capacity to adopt them in terms of skills and experience, are the best creators of a national success." (Boyko, 2008) 
The technological policy pursued by the forging-ahead countries has its origin in the 'creation' of new technologies on a basis of breakthrough basic research and advanced skills accumulated in various fields of knowledge (which is required for emergence of new 'cross science' technologies). In other words, the capability to undertake 'state of the art' basic research represents a key distinction of the forging-ahead countries. As David Mowery and Nathan Rosenberg write, “...a basic research capability is essential for evaluating the outcome of much applied research and for perceiving its possible implications..." "...Basic research can provide valuable guidance to the directions in which there is a high probability of payoffs to applied research" [Mowery and Rosenberg, (1989), p.14].

However, the existence of a basic research domain in the national economy produces additional and quite significant investment and, in general, economic risks. These risks have been increasing because basic research is quite costly: the commercial revenue on every unit of investment into basic research might be obtained in the distant future if at all. Moreover, regarding the spillover effect, follower countries (imitators) could capture the major portion of revenue obtained by innovators from new technologies.

On the contrary, countries pursuing a 'catching up' model of economic growth start their technological development from a 'selection' of technologies, borrowed from other forging-ahead countries. The main strategic goal in that case is to make the right technological choice, appropriate to a specific 'comparative advantage' of the country and consistent with specific economic problems the country faces at a certain historic period and endeavours to overcome with the new technologies 'in hand'. "The catching up pattern of economic development rests on imitation (selection, adoption and diffusion) of 'state of the art technologies' for the purposes of overcoming specific economic bottlenecks", which 'imitating' countries meet while striving to reduce a gap with the more developed countries. Rapid growth of commercial benefits enables imitating countries to cover their import needs (or to pay their external debt) while fostering an improvement in national technological capabilities (which subsequently leads to the development of applied knowledge and the introduction of certain fields in higher education). Catching up countries usually focus their national policy on developing their indigenous capabilities, therefore preferring a method of 'analytical design' (screening and re-modelling of Western made equipment) and exploiting their national advantages in scale and cost for large scale production of these 'copies', meanwhile neglecting to welcome foreign invested enterprises (FIE). The strategic goal for catching up countries is to sustain economic independence by creating a national technological chain (cluster) simultaneously improving technological absorptive capacity needed to adopt more sophisticated technologies (Boyko, 2008).

The other group of countries in accordance with a chosen type of technological policy consists of falling-behind countries. What countries could be classified as falling behind? Backward countries with extremely limited technological capabilities to absorb even unsophisticated, quite ordinary technologies of other countries could be referred to as falling behind (such as certain underdeveloped countries in Africa). Countries not regarding technological policy as a main driver for economic growth and thus deteriorating through technological degradation and devaluation of intellectual capital might also be classified as falling behind (contemporary Russia is an example). The countries that have tried to overcome their backwardness through technological policy but failed in setting the right goals, identifying appropriate tasks and supplying the 
required resources (in terms of quality, quantity and combinations) could be regarded as a falling behind countries as well.

Theoretically, a catching-up growth model is considerably more developed then falling behind or forging ahead. The spectacular success of the 'catching up growth', demonstrated by the East Asian countries made this type of economic policy quite popular among economists and political decision makers. A weakness of theoretical development for analysing a 'falling-behind' path of economic development especially for the countries in transition makes it difficult to make evaluations and to anticipate the further development of Russian economy in general and its civil aircraft manufacturing in particular.

Keeping in mind the 'catching up' type of the Russian aviation industry growth at its very beginning (first decades of 20th century), we would like to introduce the 'catching up' model more in detail.

Countries endeavouring to reach developed countries through gradually improving performance of the national industrial sector adopted the catching up model. Usually, the main strategic goal of technological policy pursued by the 'catching-up' countries is adoption of the borrowed technologies by some method obtained from the forging-ahead countries (so called 'fast second' strategy of the imitating countries). It enables those countries to reduce significantly an investment risk accompanying the process of creating new technologies and especially their first introduction on the market (commercialisation of technology). As Mowery and Rosenberg write, "The strategy of a rapid imitator, of a 'fast second' that can benefit from the mistakes of the pioneer, has much to commend it, especially when rapid rates of technical change are expected to continue". "The advantages of some sectors of being a technological follower, able to observe the technological opportunities and errors of leaders, have been exploited by a number of Japanese firms" [Mowery and Rosenberg, (1989), p.214].

Because of this technological peculiarity, the 'catching-up' countries put a special priority on the development of applied research rather then on basic research. While basic research requires substantial investments, partially yielding commercial revenues in a distant future and accompanied by the 'spillover effect', reliance on applied research, adopted by the catching-up countries, has been facilitating the commercialisation of technologies and reducing their investment risks.

Some investigators into the issue of 'catching up growth' consider its linkage with the theories of 'absorptive capacity', 'convergence' and the theory of industrial clusters. For the purposes of our study, the linkage between 'catching up' and 'convergence' is not essential. However, the link between 'catching up' on the one hand and theories of industrial clusters and 'absorptive capacity' on the other are quite important. As some investigators state, "....several conditions need to be met for technology transfer to be effective in developing countries. A crucial condition is the level of absorptive capacity" [Fu et al., (2010) p.16]. "The evidence suggests that despite the potential offered by globalisation and a liberal trade regime, the benefits of international technology diffusion can only be delivered with parallel indigenous innovation efforts, the presence of modern institutional and governance structures, and a conducive innovation system" [Fu et al., (2010) p.17].

As Bart Verspagen writes, "In order to assimilate knowledge from abroad, a country must be able to apply this knowledge in its own economic system". "...countries with relatively low levels of intrinsic learning capability and a large technological distance face a high probability of falling even further behind, while countries with relatively high 
levels of intrinsic learning capability and a small technological distance are more likely to catch up" [Verspagen, (1991), p.375].

Presumably, the pace at which any country accumulates its own technological 'absorptive capacity' characterises its capacity to successfully take off from the 'fast second' position to the position of a forging-ahead country. On the contrary, as a consequence of losing its absorptive capacity (as is the case in Russia) a country could modify its trajectory from forging ahead to falling behind. Thus, it could be stated that the lack of absorptive capacity brings the Russian aviation industry from forging ahead to falling behind.

For the development of a theoretical background for the contemporary aviation industry, establishing a link between 'catching up' growth and the theory of industrial clusters could be quite meaningful, and could apply to absorptive capacity as well.

"Industrial clusters are systems of interconnected firms and institutions located proximately within a geographic region" (Porter, 1998). This explanation of industrial clusters is quite different from the cluster understood as a group of countries with similar technological characteristics (Soete and Verspagen, 1993).

Russia has been trying to organise an aviation cluster in Ulyanovsk (2011). However, we are very skeptical about the results. Decisions taken for the establishment of the aviation cluster have no theoretical grounding and the cluster is treated as a number of enterprises already operating on the territory and needing extra financial resources for their economic survival. This is a very linear understanding of an industrial cluster.

Another problem for the clusterisation of the Russian aviation industry relates to the very complicated positive as well as negative impact of the global environment. As Enright et al. (1999) note, "The emergence of industrial clusters is a manifestation of the twin processes of economic globalization and industrial localization".

Nevertheless, starting the path into aviation from the catching up model in the beginning of the 20th century, Russia became one of the leading countries in the second half of 20th century. However, in the beginning of the $21 \mathrm{st}$ century it has lost its competitive advantage and has been further sliding into technological backwardness in this specific industrial domain. The challenging question of how to design a take-off path for the Russian aircraft industry from its dramatic fall behind has not yet been answered.

\section{Catch up of the Russian aviation industry at the beginning of 20th century}

Russian civil aviation was born around 100 years ago, in 1910. The first and most important precondition for the emergence of the Russian aerospace industry was breakthrough basic research in aeronautics and in the related spheres of knowledge undertaken by Russian scientists at the end of the 19th century. Nikolai Zhukovsky (1847-1921) was a founding father of modern aero- and hydrodynamics. He was the first to undertake a study of airflow. Nikolai Kibalchich (1854-1881), who proposed the use of rocket power in aviation, describes a means of propelling a platform by igniting gunpowder cartridges in a rocket chamber. The other great contribution to the development of basic research in aviation was made by the outstanding Russian scientist Konstantin Tsiolkovsky (1857-1935) who was an Imperial Russian and Soviet rocket scientist and pioneer of the astronautic theory. He is considered by many to be the father of theoretical astronautics. His works later inspired leading Soviet rocket engineers such 
as Sergey Korolyov and Valentin Glushko, and contributed to the early success of the Soviet space programme.

Despite breakthrough basic research, the Russian aviation industry accepted the 'catching up' model at the very beginning. Russia contracted the foreign, mostly French and UK, companies to purchase the aircrafts. However, it was predominantly assemblies (vehicles and various devices) that were transported to the Russian factories for the final production. Only a few aircrafts were produced by the Russian companies by themselves. The scale production of French models in Russia was represented by 'Farman', 'Voisin', 'Newport', 'Deperdussen', 'Bleriot' and many others.

However, various Russian experts point out that the import of foreign aircrafts produced a negative effect on the development of the national aircraft industry in Russia, which was at the stage of start-up at that period.

The first enterprises producing aircrafts emerged in Russia in 1910-1912. Up to 1917, there were 15 small enterprises, producing airplanes with a total number of workers of about 10,000. Prototypes of the Russian airplanes were under development at that time: ten prototypes were introduced in 1909 and about 200 prototypes by the end of 1912 .

The impact of the First World War on production of airplanes in Russia was quite significant. Up to 1917, about 6,200 airplanes were built in Russia including 600 airplanes before the First World War and 5,600 airplanes during the war.

This upswing in Russian aerospace research-industrial development was stopped by the post war destruction of the national economy and postponed by the subsequent October Revolution.

The October Revolution, and the Civil War which followed in Russia (1918-1922), quite negatively affected aerospace industrial production. Even during the post civil war period, when the new Russian government established a 'new economic policy - NEP' (1922-beginning of 1930s), releasing private initiatives, it was not well designed for the development of aerospace industrial production.

Outstanding Russian inventors (to name only Sikorsky, Grigorovich, Gakkel and many others) contributed strongly to the development of the aerospace industry in Russia on the eve of the 1917 October Revolution.

However, one of the most dramatic impacts of the October Revolution on further development of the Russian aerospace industry was the massive emigration of Russian top scientists and engineers. The country lost intellectual capital accumulated in aviation research and the aviation industry. Many outstanding engineers and scientists left the country and then were hired in the leading foreign countries to work for the advance of their aircraft industry. To name only Igor Sikorsky who is recognised as one of the biggest losses for Russian aeronautics. In 1912-1914, Igor Sikorsky invented state-of-the-art planes 'Grand', 'Russki Vityaz', 'Iliya Myrometc', which constituted the foundation for multivehicle aviation. In 1919, two years after the October Revolution, he left Russia for the USA where he founded the aviation company 'Sikorsky Aero Engineering Corporation'. Today, the company 'Sikorsky Aircraft Corporation' is one of the leading producers of helicopters in the world.

The reemergence of the Russian aircraft industry started at the end of $1920 \mathrm{~s}$. Between 1934 and 1941, about 22,000 fighters and 260 civil aircrafts were built.

As strange as it seems, the most favourable conditions for the emergence of Russian aerospace manufacturing as mass production was created during the implementation of the first five-year plan (1929-1933). In accordance with the first and the second five-year plans, a number of large enterprises for airplane and engine production were established 
in Russia; this in turn enhanced industrial capacities in related industries like iron metallurgy, non-ferrous metallurgy and many others. Growth in the production volumes in aerospace manufacturing was spectacular. Between 1933 and 1938 it increased 5.5 times.

Resulting from that industrialisation programme, a large aerospace industry capable of designing and producing a large number of planes of different types was established by the end of the 1930s (Stepanov, 2009). These ambitious industrial plans were matched by an appropriate budget policy - the share of the Soviet military budget spent on the development of aviation and aerospace manufacturing reached $40 \%$.

USSR's model in the aircraft industry started as 'catching-up', exemplified by the 'Li-2' model - a license-built version of the Douglas DC-3, but was transformed into a forging-ahead model a few years later. After World War II, the Russian aircraft industry has developed as a locked industrial cluster independent of foreign technologies, skills and assemblies.

At the very beginning of the Second World War, the USSR's air force had been catastrophically destroyed by the invading German air force. The war began on June 22, 1941 and ended on December 31, 1941; the losses included 21,200 planes. Afterwards, plane production grew quite rapidly: from 7,900 planes in 1941 to over 40,000 in 1944 . On Victory Day, May 9, 1945, the USSR had 47,300 warplanes including 9,700 bomber aircrafts, 10,100 battle planes and 27,500 fighter aircrafts. It was a spectacular introduction of the national aviation industry, which maintained the leading positions of the Russian, mostly military, aviation on the world market.

During the early post war years, the USSR's civil aviation was equipped only with 470 transport planes: 'Li-2', 'C-47', a small number of foreign transport planes and about 2,000 light planes: 'Po-2', 'UT-2'.

In 1956, the first aircrafts equipped with gas-turbine engines ('Tu-104', 'Il-18' and 'An-10') were presented on the domestic market. In 1957, the commercial exploitation of planes 'Il-18' and 'An-10' started. A few years later the other type of plane specifically for intercontinental flights was designed; it was the 'Tu-114' made for carrying up to 170 passengers. During the 1960s and 1970s, the only USSR aviation company, Aeroflot, was supplied by the new aircrafts equipped with gas-turbine engines: 'TU-124', 'Tu-134' (short-haul), 'An-24', 'An-26', 'Yak-40' (regional jets) and 'Il-62' (long range aircraft). At the beginning of the 1970s, the new medium range airliner ' $\mathrm{Tu}-154$ ' was designed and delivered to 'Aeroflot'. Later on 'Aeroflot' started to exploit jumbo jet 'Il-86'. In 1977, 'Aeroflot' undertook the first passenger flight 'Moscow-Alma-Ata-Moscow' on the hypersonic aircraft 'Tu-144'. The introduction of the new aircrafts 'An-12' and 'Il-76', which started at the end of the 1970s, significantly increased the tonnage and capabilities of cargo aviation in Russia.

To the end of the 1980s, the USSR has produced about a quarter of civil aircrafts and $40 \%$ of military aircrafts in the world. Between 1961 and 1990, the USSR supplied 60 countries with aeronautics production (including 7,500 units of aircrafts and 4,500 units of helicopters). They were predominantly sold to the countries under the USSR's 'political umbrella' - certain countries in Eastern Europe, Africa and East Asia.

We have some assumptions on how the USSR has gained leading positions on the world market as a producer of aircrafts; they are the following: 
1 In the USSR, civil aerospace production was nested within the military-industrial complex. The best intellectual resources were mobilised in the military sector, which resulted in new state-of-the-art technologies created in the R\&D laboratories on a non-stop basis and then diffused into the civil aircraft production through a 'spin off effect'.

2 Decisive role of the national government in aerospace industrial production. Quite contrary to the market forces, the government insured:

a substantial financial resources from the budget to provide long-term investments with a long turnover period

b substantial, stable and large demand of aeronautics production

c supplied aircraft producers with required resources in terms of quality and quantity

d established stable terms of production (costs, prices etc.)

e provided free access to breakthrough knowledge and technologies

f educated highly qualified personnel in state universities and established a life-long learning system.

3 Specific Russian advantage represented by its geographic space. The USSR had a large territory with a length over 9,000 kilometres from the west (Kaliningrad) to the east (Vladivostok). During Soviet times, when the government pursued an autarky policy, the domestic market was protected from foreign companies, which provided the national companies with special advantage in terms of large geographical scale and regional diversities for aerospace production and sales.

\section{Russian aircraft industry today: catching up or falling behind?}

During the market reforms, started in 1991, the model of forging ahead development adopted in the USSR' military production in general and in the aviation industry in particular was dismantled.

At a certain stage of the USSR's economic development, increasing military spending became an obvious restriction for further economic growth in general and civil aviation in particular. Besides, total militarisation of the economy, absorbing national resources at the same time, restricted competitive development of the civil production. The US economy was similarly affected, as Mowery and Rosenberg (1989) write: "military (and space) programmes have notoriously subordinated cost considerations to the improvement of performance - often incurring very high costs for very small improvements, few of which are relevant to the civilian market" (p.143).

Besides, "technological development in this industry, as in others, has relied heavily on technological spillovers from military to civilian applications. Such spillovers now appear to be less significant, however, and their very direction may have been reversed in a number of aircraft technologies" [Mowery and Rosenberg, (1989), pp.188-189].

The transition to market economy, which started in the USSR in the middle of the 1980 s, destroyed the favourable conditions for development of the national aerospace industry through the following processes: 
- The demilitarisation of the national economy produced quite negative impact on the development of both military and related civil aviation. It is worth noting that the industrial proportion between military and civil aircrafts in the USSR was 80:20. Conversion of the military production caused a reduction in production facilities, devastated $R \& D$ and undermined the base for experimental development.

- The breakdown of the USSR in 1991 ruined the technological relations between the ex USSR republics. Henceforth, after losing substantial portions located in the different republics, the USSR aerospace industrial cluster was liquidated.

- Starting in the early 1990s, privatisation was implemented regardless of technological links between enterprises located in different Russian regions. This caused a destruction of technological ties between various technological chains within various industrial clusters in general and within the aerospace industrial cluster in particular.

- Continuous liberalisation of foreign trade. Increasing import of foreign aircrafts has produced a negative impact on the national aircraft industry. Because national air carrier companies preferred to purchase foreign aircrafts, the national producers lost the domestic market and were forced to reduce their production facilities.

- A widening gap between Russian regions in terms of economic capabilities has been affecting economic scale. Today, over $20 \%$ of the Russian population resides in two cities and their suburbs - Moscow and Saint Petersburg, where concentration of the national financial resources is about $70 \%$. Obviously, the market demand for long distance flights from the remote Russian regions, like the Russian Far East, dramatically dropped. According to some estimations the number of passengers on the inland lines has dropped from 142 million to 35 million during the period from 1990 to 2005 .

- Unfavourable market terms for development of the Russian aerospace industry (including increasing costs, rapidly growing fuel prices, decreased mass demand of flights and many others). The production of new aircrafts became single-pieces. The Russian production of civil aircrafts counted only four copies in 2000 (which was equal to the weekly production of Boeing or Airbus at that time), 11 in 2003, 17 in 2004 and 18 in 2005.

- Increasing investment risks in the area of commercial aircraft manufacturing. Focused on getting short-term revenue, the Russian companies are not motivated to consider that a long-term investment strategy is what they really need to sustain their market positions.

Moreover, since April 1, 2002, the European Union has prohibited the passage of Russian aircraft over their territories because of inappropriate noise conditions.

Due to many circumstances, the share of Russian aircrafts in the world aviation market has dropped to $2 \%$.

Today, technically and technologically it is very difficult for Russia to catch up to the leading aircraft countries. During ten years of sporadic economic decisions, the country has lost its huge human capital, which worked for the industry before. According to some estimates, the Russian civil aircraft production lags behind its Western counterparts by about seven years. As for the vehicles, the gap is even more dramatic - about 20 years. 
It became evident that the development of aircraft manufacturing in market terms is quite different from that within a military complex. "Careful monitoring of aircraft performance is necessary so that subsequent models of the same design can incorporate the lessons learned from the operating experiences of early models. Airlines, along with technologically sophisticated purchasers in other industries, are major sources of suggestions for change in aircraft design, maintenance, and even production practices. The integration of after-sales maintenance, and marketing data with design engineering that the firms in this industry have developed to take advantage of their users' experience is an excellent example of the ways in which the characteristics of this industry's product technology have influenced the organization of R\&D” [Mowery and Rosenberg, (1989), p.177].

The other quite important feature of the civil aircraft industry is related to 'economies of scale', which means that this specific industry could function only with the gradual increasing in aircraft copies manufactured and traded on the global market, "...effectiveness of the process innovations directly depend on the domestic market scale: the larger is the number of national companies adopting a certain type of process innovation the higher would be the accumulated commercial revenue and, hence, the whole economic effect for the country" [Boyko, (2008), p.2].

The problems met by the Russian aircraft industry had both federal and regional dimensions. In this regard, the case of Samara region represents one of the stories of failure in Russian civil aircraft production (Isupov, 2006).

Before leaving the USSR, the Samara's factory 'Kuibyshev aviation factory' was one of the biggest in the country manufacturing civil aircrafts, mostly 'Tu-154' either for supplying the national air carrier company 'Aeroflot' or for exports to other countries: Afghanistan, Bulgaria, Hungary, Yemen, North Korea, Cuba, Romania, Syria, Czechoslovakia, and Ethiopia. In 1990, the government terminated their procurements of aircraft production. The breakdown of the Council for Mutual Economic Assistance ${ }^{1}$ has produced a very negative impact on aircraft production as well. Between 1994 and 2001, Samara's aviation factory was subject to bankruptcy procedure. Production has dropped to its lowest level since its establishment (Table 1).

Table 1 Civil aircraft production in Samara city

\begin{tabular}{lcccccccccccc}
\hline Year & 1992 & 1993 & 1994 & 1995 & 1996 & 1997 & 1998 & 1999 & 2000 & 2001 & 2002 & 2003 \\
\hline Number & 39 & 37 & 10 & 9 & 1 & 3 & 6 & - & 1 & 2 & - & 1 \\
\hline
\end{tabular}

Source: Isupov (2006)

\section{Innovation system in the Russian aviation industry}

The establishment of the national aeronautic centre - Central Aero Hydrodynamic Institute (TsAGI) in 1918 represented a very important milestone in the development of the Russian aeronautics. Nicolai Zhukovsky created and managed this innovation centre. It was the first scientific institute in Russia to combine basic studies, applied research, structural design, pilot production and testing in one place. TsAGI is a pioneer in the theory of flutter, along with many other theories, applications and experimental studies undertaken since its foundation. 
Advanced aeronautics in the Soviet Union (Russia) and its increased technological and economic complexity made it necessary to establish a special institution to educate highly qualified personnel for industry-related R\&D, manufacturing and operating. To serve these needs, Moscow Aviation Institute (now Moscow Aviation Institute - State University of Aerospace Technologies - MAI) was established in 1930.

Alongside with the civilian system of innovation, the 'innovation system in jails' was also established in Russia during the period of Stalin's industrialisation. We have to underline here that the majority of breakthroughs in aviation know-how during the 1930s originated in jails and concentration camps ${ }^{2}$. One of these was Nicolai Policarpov's invention of the 'U-2' plane, in 1929-1930 during his imprisonment in Butirskaya jail. During the 1937-1940 period, a number of the best Russian aviation inventors such as a famous aircraft designer Andrei Tupolev, Sergey Korolev - Soviet rocket engineer and the father of practical astronautics, and many others, were jailed as public enemies.

Today, the research base in Russia comprises 56 science-research institutes (NII), 93 design bureaus (OKB), and 20 large scientific centres, including six having the status of science-technical centres.

The leading R\&D institutions in aviation are the following:

- $\quad$ research institutes and centres

1 leading aeronautics institute - Central Aero hydrodynamic Institute (TsAGI), named after N.E. Zhukovsky

2 Central Institute of Aviation Motor Construction (CIAM)

3 'State Research Institute of Aviation Systems' (State Scientific Centre of Russian Federation)

4 Flight Research Institute named after M.M. Gromov (LII)

5 'All Russia Scientific Research Institute of Aviation Materials' - state research centre of the Russian Federation (VIAM)

6 Siberian Research Institute of Aviation named after S.A. Chapligin in Novosibirsk

- universities

1 Moscow Aviation Institute (now Moscow Aviation Institute - State University of Aerospace Technologies - MAI)

2 Moscow Institute of Physics and Technology

3 Moscow State Technical University named after N.E. Bauman (MSTU)

4 Russian State Technological University named after K.E. Tsiolkovsky

5 Samara State Aerospace University named after academician S.P. Korolev

6 Kazan State Technical University named after A.N. Tupolev

7 Ufa State Aviation Technical University

- the largest design bureaus

1 design bureau named after S.V. Ilushin

2 design bureau named after A.S. Yakovlev

3 design bureau named after A.N. Tupolev

4 design bureau named after P.O. Sykhoi 
5 design bureau named after O.K. Antonov

6 design bureau named after N.I. Kamov

7 design bureau named after A.I. Mikoyan and A.M. Gurevich

In addition, every aviation plant in Russia has its own R\&D laboratory to meet the specific requirements of certain industrial processes.

Today, the Russian Government is considering the modernisation of the national innovation system in aviation, based on each of the nine stages of the innovation cycle:

- evaluation of new technology impact

- comparison of alternatives, making a choice of the technological concept

- identification of key technologies, evaluation of risks

- laboratory testing

- testing of the models in conditions close to real situations

- $\quad$ simulation testing of the model

- experimental testing of the prototype

- factory testing of the prototype

- $\quad$ testing of the prototype.

The research institutions usually undertake the evaluation of the impact of the new technology. The first stage involves an examination of the basic technology. The second to fourth stages represent the development of technology; the fifth to sixth involve the demonstration of technology. The model is created during the fifth stage, the prototype during the sixth stage. The government covers all expenditures. After simulation testing of the prototype, the decision on its further development is taken. From then on, the industry takes its own responsibility for the further development of the prototype through the other stages of the innovation cycle and it also makes its own investment decisions in terms of market strategy.

The heart of this system is represented by the state scientific centres - Tsagi, VIAM, TSIAM, GosNIIAS, and LII.

\section{Industry}

In Russia, large science-production complexes (nauchno-proizvodstvennii complex NPK), based on a closed technological cycle are at the heart of the aerospace industry. Each NPK comprises a design office, R\&D laboratories, testing units, production facilities, which undertake applied research, engineering development, production of civil and military aircrafts, modernisation and modification of products and various related services.

According to 2002 data, there are about 70 plants in Russia involved in the production of aircrafts, including: 20 plants producing aircrafts and helicopters, over 20 plants producing aviation engines, about 30 plants producing various devices, systems and equipments for aviation production. 
In 2002, the total number of personnel working for the aviation plants and related businesses was about 516,000 (it was one million during the later Soviet times), including: in science $-40,000$ people, in the development of aviation techniques about 70,000 people, in mass production - over 400,000 people.

The largest NPK and aviation plants are:

- aviation company-holding 'Sukhoi' (comprised OAO designing bureau 'Sukhoi', ZAO 'civil aircrafts of Sukhoi', APO named by Gagarin in Komsomolsk-on-Amur, Taganrog aviation NPK named by Beriev, Novosibirsk FPO named by Chkalov and corporation 'Irkut');

- $\quad$ RSK 'Mig'

- Kazan aviation industrial holding named after Gorbunov

- The Open Joint Stock Company 'Ilyushin Aviation Complex'

- OAO Nizhny Novgorod Aviation Plant Sokol

- OAO 'Tupolev'

- Ulyanovsk aviation plant (industrial complex) 'Aviastar-SP'

- Voronezh Shareholder Aircraft-Building Society (VASO)

- Samara aviation plant

- Kumertau helicopter plant

- Arseniev aviation plant.

In most cases the Russian government holds a major share of stocks in NPK and of large aviation plant capital.

The other Russian aviation company, Irkut, represents another type of shareholding with the participation of foreign companies (Figure 1) ('The international aviation industry: in the high turbulence zone', 2007). EADS (EADS - European Aeronautic Defense and Space Company) is a foreign investor in 'Irkut'.

Figure 1 Shareholders of 'Irkut' aviation company (see online version for colours)

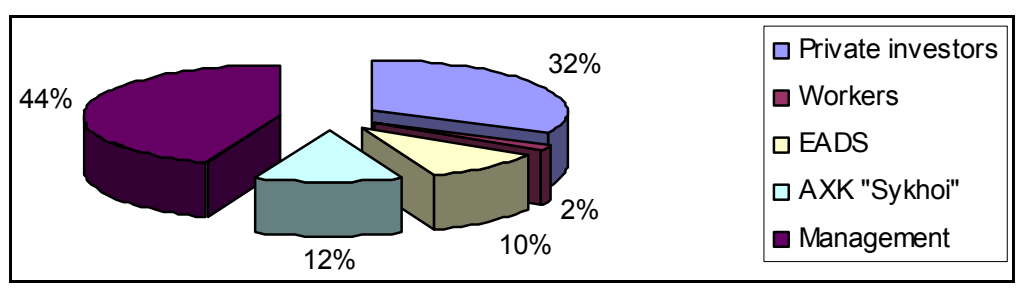

The main idea for the development of the aircraft industry consists in merging the financial, intellectual, labour and material resources under a state-private company. In 2006, the Russian government took a decision to consolidate resources: financial, intellectual, labour, capital to enlarge aviation production by establishing a government-private company - Joint Stock Company 'United Aircraft Corporation' 
(UAC). UAC [in Russian: Obyedinyonnaya Aviasroitelnaya Korporatsiya (OAK)] is a Russian open joint-stock corporation with a majority stake belonging to the Russian government, which consolidates Russian private and state-owned aircraft construction companies and assets engaged in the manufacture, design and sale of military, civilian, transport, and unmanned aircraft (Dementiev, 2009).

The holding UAC comprises Rossimuchestvo (the government), and the private stake holders - 'Irkut' (which includes Beriev, Irkutsk Aviation Plant, Russian Avionics Design Bureau, IRKUT AviaSTEP Design Bureau and BETA AIR), 'Aviaexport', 'Ilushin Finance Ko', aviation enterprises in the city Novosibirck and Komsomilsk-on Amur, the Open Joint Stock Company Ilyushin Aviation Complex, OAO Nizhny Novgorod Aviation Plant Sokol, OAO 'Tupolev' and financial leasing Corporation. It was recently announced that the TAPO factory in Tashkent, Uzbekistan, would also become a subsidiary of the group.

In 2008-2009, over $80 \%$ of whole assets in the Russian aviation industry were integrated by the UAC.

In 2009, UAC delivered 90 aircraft, including 17 passenger models. This figure includes 31 MiG-29 and two Su-34 fighter jets produced for the Russian Air Force.

The UAC production line includes the following civil, cargo and special purposes aircrafts:

- $\quad$ civilian products (Antonov An-148, Ilyushin Il-114, Tupolev Tu-204, Sukhoi Superjet 100, MS-21)

- Cargo (Ilyushin Il-76, Ilyushin Il-96-400T, Ilyushin Il-112, Ilyushin Il-114T, Irkut Multirole Transport Aircraft, Tupolev Tu-204C)

- $\quad$ special purposes aircraft (Beriev Be-200).

UAC is the larger supplier of Russian commercial aircrafts for the national air companies. The figures for 2009 are indicated in Table 2.

Table 2 UAC procurement of commercial aircrafts for the Russian air companies in 2009

\begin{tabular}{lcc}
\hline Type of aircraft & Quantity (units) & Operator \\
\hline Il 96 & 1 & Special United Air group \\
& 3 & FL 'Polet' \\
Tu-204 & 2 & Red Wings \\
& 1 & Cubana de Aviacion \\
& 1 & Air Koryo \\
& 1 & VTB-Lizing \\
Tu-214 & 2 & Department of Russian Presidential Affairs \\
& 1 & AK 'Transaero' \\
An-148 & 2 & GTK 'Russia' \\
TOTAL & 14 & \\
\hline
\end{tabular}

Source: 'Perspective civil aviation industry in Russia' (2010)

UAC has created a comprehensive internal innovation system, depicted in Figure 2 (Fedorov, 2010). 
Figure 2 The system of modernisation and innovation management and financing, UAC

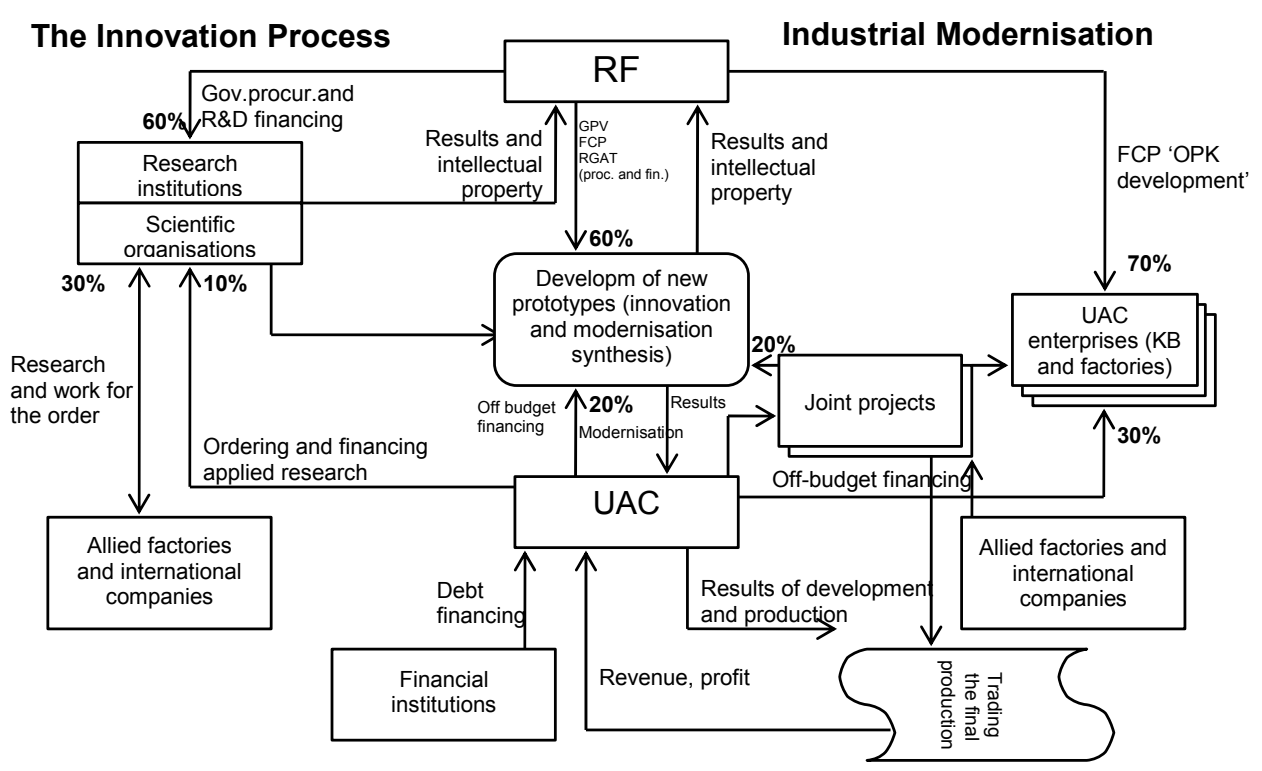

Notes: Formula of the system: the developers own the results, the government owns the rights. Direction for the actions: to extend the rights of the developers in the commercialisation of technologies but under government control and assistance.

\section{Administrative guidance}

The administrative guidance provided for the Russian aircraft industry is restricted by the financial assistance.

The major financial measures taken by the Russian Government to enforce development of the aerospace industry include: direct financial procurement (goszakaz) (the estimated goszakaz on aviation production for nine months of 2009 was 59.7 billion rubles or about $\$ 2$ billion.); direct financial support through government sponsored federal target programmes.

However, plans for civil aircraft production, elaborated by the Russian government, have not been accomplished on time. As a result, the national airline companies were supplied with only 14 aircrafts (2009) instead of the planned 22.

The huge financial government support provided to the leading Russian aircraft producers has not yielded substantial revenues yet (Slivitski, 2009). In 2009 the general debt of the UAC was estimated at more than 70 billion rubles (about $\$ 2,4$ billion). With the debt of the affiliated companies, the total amount is 119 billion rubles (about $\$ 4.2$ billion). Probably the huge company debt was the main reason for the Russian government to replace UAC General Director Aleksei Fedorov by Mikhail Pogosyan in March 2011 (the official reason was the failure of the innovation policy pursued by the $\mathrm{UAC})$. 
Despite the fact that the provision of financial resources is not the key factor in enforcing the competitiveness of the national aircraft industry, the Russian government announced the next financial plan to spend about 5 trillion rubles (about $\$ 180$ billion) from the federal budget until 2020 to develop the whole set of activities related to the aviation industry (both military and civil, including airport modernisation) (Medvedev, 2011). According to this plan, civil aircraft production per se will obtain about $\$ 36.5$ billion from the government and private investments.

\section{SSJ-100 as a forging-ahead model}

Sukhoi Superjet 100 (SSJ-100) is recognised as one of the most prospective aircraft models for Russian civil aviation (Oleinikov, 2010).

The Sukhoi Superjet 100 is a modern, fly-by-wire regional jet in the 75- to 95-seat category. The Superjet 100 is produced by the Russian aerospace firm Sukhoi's civil division, of which Finmeccanica of Italy owns 25\%. The jet is being developed in collaboration with Finmeccanica subsidiary Alenia Aeronautica. The Italian design group Pininfarina designs optional interiors, and in 2007 Alenia Aeronautica and Sukhoi Holding formed SuperJet International, a joint venture (51\% - Alenia Aeronautica, and $49 \%$ - Sukhoi Holding) based in Venice. This holding is responsible for marketing, sales and aircraft delivery as well as for worldwide logistic support for the Superjet 100.

Sukhoi Superjet 100 is designed to compete with the Embraer E-Jets and the Bombardier CRJ programmes. Sukhoi claims that the SSJ will have $10 \%$ to $15 \%$ lower operation costs than its Embraer or Bombardier counterparts, for the price of $\$ 31.7$ million.

The design meets the specific requirements of airlines in Russia, the CIS, the USA, and the EU.

The assembly line for all versions of the plane is located in the facilities of Komsomolsk-on-Amur Aircraft Production Association (KnAAPO) on the Russian Far East, while Novosibirsk Aircraft Production Association (NAPO) focuses on component production. The two companies have been heavily investing in upgrading their facilities, and are expected to produce 70 airframes by 2012 .

As of January 2009, the first two aircrafts have completed over 90 flights, totalling 300 hours; the engines have accumulated around 2,300 hours in flight and ground tests.

However, most of the problems are with the SaM146 engine, developed by PowerJet, which is a joint project between the Russian Saturn and the French Snecma. Work on its final design has been almost entirely completed and certification is already done more than $90 \%$, but the problems remain.

The first passenger flight of SSJ-100 was undertaken in April, 2011 from Erevan (Armenia - ex USSR republic) to Moscow (Russia). However, exploitation problems still remain.

SSJ-100 will be competing with the Canadian Bombardier (CRJ-900) and Brazilian Embraer (ERJ-190/195). However, based on exploitation costs the Russian aircraft would be about $8 \%$ better than its foreign analogues. Yet, several recent mechanical problems and a very recent crash (in May 2012) show that the Superjet 100 is not yet ready to compete with the two market leaders of regional jets. 


\section{Falling behind rather than forging ahead of the Russian aviation industry}

However, despite the government policy focused on the reestablishment of the national aircraft industry, the Russian air companies rely mostly on purchasing foreign aircraft, predominantly Boeing and Airbus. For instance, up to April 2010, the largest air company in Russia and in the Commonwealth of Independent States (CIS) - Aeroflot has purchased:

- 15 airbus A319

- 33 airbus A320

- 16 airbus A321

- 10 airbus A330

In the meantime, Aeroflot has exploited only six Russian made models of the aircraft Il-96-300. And according to the contract signed in July 2010 by the Russian company Rostechnologii (Russian Technology) and the US Boeing, Russia will buy 50 B737 commercial jetliners in a deal worth up to $\$ 4$ billion (Bulin, 2010).

Also, the industry is supplied with foreign components and assemblies (including engines, electronics, etc.) to produce airliners in Russia. For example, the majority of aircrafts manufactured by the company 'Sukhoi' is equipped with French avionics. Unfortunately, this does not represent an implementation of an explicit technological policy (forging ahead or catching up) to improve Russian absorptive capacity in the industry and acquire competence in this specific market niche.

\section{Russian civil aviation industry challenges}

The main challenges for the Russian aircraft industry are the following:

- A substantial financial debt. The cost of production is very high, sale volumes are quite low (the national aircrafts on the domestic market are replaced by foreign aircrafts while the traditional offshore markets that existed before for Russian aircrafts are lost).

- The upcoming participation in the World Trade Organization (WTO), which will make it even more complicated to support any start-ups in the aviation industry.

- A 'blockage effect' on the world aircraft markets.

The only way to overcome the bottlenecks in the development of the Russian aircraft industry is to elaborate and implement a well-designed innovation plan. Probably, at the very beginning it could be a catching-up plan of development. However, a catching-up model implies that:

1 The country could gain a significant advantage in production costs (which is not appropriate for Russia with its comparatively high cost of labour and energy resources making production uncompetitive with regard to Brazilian, Chinese or Indian aircrafts). 
2 A catching up country should extend its market share, in order to make production profitable, especially in the aircraft industry. Obviously, Russia has been facing a substantial problem with market expansion.

3 The catching-up strategy involving gradual accumulation of technological capabilities in the country should be a predominant strategy. Meanwhile Russia has been pursuing contradictory economic trajectories: one is based on the increasing trade in oil and gas, and the other is focused on technological modernisation of industries. It is not certain that in a country relying on trade in raw resources the development of aircraft production has a solid perspective.

The basic requirement for the survival of Russian aircraft production is the gradual introduction of new technologies enabling the achievement of technically superior models, improved quality and reduced costs and prices of the aircrafts. However, a number of crucial problems must be solved beforehand.

Technological renovation is a very costly process. Russian companies making revenues of about $\$ 5$ billion cannot support the required $R \& D$ through their own investment. They find themselves in a deadlock situation: Russian companies need to be more innovative to survive on a very competitive market, and to increase their revenues, but they are unable to sustain substantial R\&D efforts.

The other problem is the uncertain strategic method for the development of the Russian aircraft industry. Decision makers should take a final decision at the crossroads of the technological modernisation of the industry: to be innovative or, on the contrary, imitative. Some experts argue that there are no reasons to copy 'the yesterdays in production' and that the only way to make a progress is to introduce breakthrough technologies in the industry. Other experts insist that the country has no chance to move forward if it continues to rely on backward vehicle production instead of copying state-of-the-art foreign technologies.

\section{Conclusions}

Development of aviation manufacturing represents an important strategic objective for Russia. However, there are many reasons why it has not been achieved yet:

1 Huge intellectual losses in the industry - brain drain (inland and outland) from aerospace manufacturing.

2 Substantial wear and tear deterioration of capital assets and huge amounts of new investments required for their replacement and modernisation.

3 The loss of traditional markets for Russian (Soviet) aerospace production, including substitution of the Russian-made aircrafts on the domestic market by imports (with outdated copies as well).

4 New Russian civil jets are not competitive on the world market in terms of ecological and other requirements.

5 Interruption of technological chain in the aviation industry, which occurred during Soviet times. The most meaningful is Russia-Ukraine-Uzbekistan cooperation. 
6 Incoherence in terms of prices, quantities and timeframes among various national suppliers and producers of aviation-related products.

7 Significant dependence of the Russian producers on foreign suppliers of aviation components.

But the main reason is the crash of the large state-owned production and technological system previously established in aviation manufacturing, which is not yet replaced by an efficient market-driven system of production and marketing.

There are no explicit strategic objectives sustained by appropriate resources in terms of quality, quantity, timeframe and prices in Russia making it possible to meet the challenges arising from domestic and foreign markets. An unclear government policy increases risks for private investors. This probably represents the most crucial weakness of the Russian aircraft industry today.

\section{Acknowledgements}

The author is very thankful to Prof. Jorge Niosi, Canada's Chair on Management of Technology, for granting the opportunity to work at the research on the international civil aircraft industry.

\section{References}

'Perspective civil aviation industry in Russia' (2010) (in Russian), available at http://www.memoid.ru/node/Perspektivy_grazhdanskogo_aviastroeniya_Rossii\#.D0.9F.D0.B5 .D1.80.D1.81.D0.BF.D0.B5.D0.BA.D1.82.D0.B8.D0.B2.D1.8B (accessed on 21 April 2012).

'The international aviation industry: in the high turbulence zone' (2007) Aviation industry in Russia, (in Russian), available at http://www.valut-tranzit.kz/analitika/mirovoy-aviaprom-vzone-vyisokoy-turbulentnosti-vii-aviastroenie-v-rossii/ (accessed on 14 May 2012).

Boyko, I. (2008) 'Central and East European countries: innovation leapfrog versus 'path dependence', 5 June, Munich Personal RePEc Archive, MPRA, available at http://mpra.ub.uni-muenchen.de/13783/ (accessed on 12 June 2012).

Bulin, D. (2010) 'Who will save the Russian civil aircraft industry?', (in Russian), available at http://www.bbc.co.uk/russian/russia/2010/10/101030_russia_air_industry.shtml (accessed on 25 April 2012).

Dementiev, V. (2009) 'UAC and the development of the Russian aviation industry', (in Russian), available at http://www.cemi.rssi.ru/publication/e-publishing/dementiev/Bulliten3-2009b.pdf (accessed on 16 March 2012).

Enright, M.J., Scott, E.E. and Leung, E. (1999) Hong Kong's Competitiveness: Beyond the Asian Crisis, Hong Kong Trade Development Council, Hong Kong.

Fedorov, A. (2010) 'A UAC development strategy: from modernization towards innovations: the model for increasing profitability and compatibility', Presentation, (in Russian), available at http://www. i-russia.ru/media/files/41d2e875a843ba13f6bc.ppt (accessed on 28 April 2012).

Fu, X., Pietrobelli, C. and Soete, L. (2010) 'The role of foreign technology and indigenous innovations in emerging economies: technological change and catching up', September, Inter-American Development Bank, Institutional Capacity and Finance Sector, Technical Notes No. IDB-TN-166, available at http://idbdocs.iadb.org/wsdocs/getdocument.aspx? docnum $=35337751$ (accessed on 22 May 2012). 
Isupov, A. (2006) 'The main directions for the state intervention into the civil aircraft industry during the transition to the market economy (a sample of Samarskaya oblast', Bulletin of Samara State University, No. 8 (48), (in Russian), available at http://www.ebiblioteka.lt/ resursai/Uzsienio\%20leidiniai/SGU/Vestnik_HumN/2006-08/hum0608_12.pdf (accessed on 16 May 2012).

Medvedev, D. (2011) 'Financial support for the Russian aviation will amount 5 trillion rubles up to 2010', (in Russian), available at http://all-for-news.ru/?p=1075 (accessed on 12 April 2012).

Mowery, D. and Rosenberg, N. (1989) Technology and the Pursuit of Economic Growth, Press Syndicate of the University of Cambridge, New York, USA and Melbourne, Australia.

Oleinikov, V. (2010) 'About a strategy in the development of the national aviation industry', (in Russian), On the Strategy of the National Aviation Manufacturing Development, available at http://www.atminst.ru/up_files/aero_o_strategii_razvitiya_nacional_nogo_aviastroeniya.pdf (accessed on 25 May 2012).

Porter, M.E. (1998) Competitive Strategy: Techniques for Analyzing Industries and Competitors, Free Press, New York.

Slivitski, A. (2009) 'Government policy in innovation development of the aviation industry', (in Russian), available at http://www.sciteclibrary.ru/rus/catalog/pages/10245.html (accessed on 16 March 2012).

Soete, L. and Verspagen, B. (1993) 'Technology and growth: the complex dynamics of catching up, falling behind and taking over', Explaining Economic Growth: Essays in Honor of A. Maddison, University of Groningen, Amsterdam; North-Holland, New York.

Stepanov, A. (2009) The Development of the Soviet Aviation before the World War II (1938-1941), (in Russian), Russian Foundation for Promotion of Education and Science, Moscow.

Verspagen, B. (1991) 'A new empirical approach to catching up or falling behind', Structural Change and Economic Dynamics, Vol. 2, No. 2, pp.359-380.

\section{Notes}

1 The member countries were USSR, Poland, Czechoslovakia, Hungary, Bulgaria, German Democratic Republic, Mongolia, Cuba, associated member: Yugoslavia and observer countries: Angola, Afghanistan, Yemen, Nicaragua, Laos, Mozambique, Ethiopia.

2 Sharashka (sharaga) - slang name for the secret NII and KB subordinated to the NKVD/MVD of the USSR, which worked with inmate engineers. In the system of the NKVD, these were called 'special technical departments' (STU), 'special design bureau' (OKB), and similar abbreviations with numbers. 